\title{
RELASI KEPALA DESA DAN BADAN PERWAKILAN DESA DALAM PEMANFAATAN DANA DESA DI KECAMATAN NAMLEA
}

\author{
Salma Yusuf ${ }^{1}$, M Chairul Basrun Umanailo ${ }^{2}$, Nirwana $\mathrm{AR}^{3}$ \\ ${ }^{1}$ Fakultas Hukum Universitas Iqra Buru \\ chairulbasrun@gmail.com
}

\begin{abstract}
ABSTRAK
Tujuan penelitian ini adalah mendeskripsi relasi kepala desa dan BPD dalam pemanfaatan dana desa untuk pembangunan masyarakat. Penelitian dilakukan di Kecamatan Namlea Kabupaten Buru dengan sampel kasus meliputi wilayah Desa Namlea, Desa Jamilu dan Desa Lala. Metode penelitian yang dipergunakan dalam penelitian ini menggunakan metode studi kasus pendekatan kualitatif. Jumlah informan yang akan diwawancarai sebanyak 40 orang yang diambil secara purposive dengan pertimbangan informan dianggap sebagai pihak-pihak yang terkait dan dapat memberikan informasi memadai untuk mencapai tujuan penelitian. Teknik analisis yang digunakan dalam mengikuti konsep yang diberikan Miles and Huberman dan Spradley. Miles and Huberman, bahwa aktivitas dalam analisis data kualitatif dilakukan secara interaktif dan berlangsung secara terus menerus pada setiap tahapan penelitian sehingga sampai tuntas, dan datanya sampai jenuh. Aktivitas dalam analisis data yaitu reduksi data (data reduction), penyajian data (data display), penarikan kesimpulan atau verifikasi (conclusion drawing/ verification). Hasil kajian penelitian mengemukakan tahap perencanaan pembangunan desa di kecamatan Namlea telah dilakukan dengan cukup baik, dengan adanya keterlibatan dan partisipasi masyarakat secara umum. Keterlibatan lembaga desa untuk pengelolaan dana desa memungkinkan untuk kolaborasi ide dan sumber daya sehingga pada tahap implementasi dana desa dapat dihasilkan optimasi untuk mencapai target.
\end{abstract}

Kata kunci: Relasi, Desa, Dana Desa, Kerjasama

\begin{abstract}
This study aims to describe the relationship between the village head and BPD in utilizing village funds for community development. The study was conducted in Namlea Sub-District, Buru District, with case samples covering the Namlea Village, Jamilu Village, and Lala Village. The research method used in this study uses a case study method with a qualitative approach. The number of informants who will be interviewed as many as 40 people who were taken purposively with the consideration of informants are considered as relevant parties and can provide adequate information to achieve research objectives. The analysis technique used in following the concepts given by Miles and Huberman and Spradley. Miles and Huberman that the activities in qualitative data analysis are carried out interactively and take place continuously at each stage of the study so that it is complete, and the data is saturated. Activities in data analysis are data reduction, data display, conclusion drawing, or verification. The research study results revealed that the stage of village development planning in Namlea sub-district had been carried out quite well, with the involvement and participation of the community in general. The participation of village institutions in village fund management allows for the collaboration of ideas and resources so that at the implementation stage, village funds can be optimized to achieve targets.
\end{abstract}

Keyword: Relation, Village, Village Funds, Cooperation

1. Fakultas Hukum Universitas Iqra Buru

salma.uniqbu@gmail.com

2. Fakultas Pertanian dan Kehutanan Universitas Iqra Buru chairulbasrun@gmail.com

3. Fakultas Keguruan dan Ilmu Pendidikan Universitas Iqra Buru nirwana.arfin@gmail.com 


\section{PENDAHULUAN}

Kecamatan Namlea merupakan Ibukota Kabupaten Buru terdiri dari 11 desa dan 9 dusun. Luas wilayah Kecamatan Namlea 226,55 $\mathrm{Km}^{2}$ serta yang memiliki jumlah penduduk terbanyak di Kabupaten Buru. Penduduk Kecamatan Namlea menurut data Biro Pusat Statistik tahun 2017 adalah 34.326 jiwa. Jumlah ini bertambah terus setiap tahun dengan laju pertumbuhan penduduk 6,26 persen (BPS-Statistics Indonesia, 2017). Dengan pertambahan penduduk ini, secara otomatis mengakibatkan semakin tingginya tingkat kepadatan penduduk yang menandakan bahwa semakin banyak pula permasalahan yang akan muncul di tengah-tengah kehidupan bermasyarakat. Berdasarkan Pasal 23 ayat 1 Undang-undang Dasar Tahun 1945, pendanaan pembangunan dan alokasi Anggaran Pendapatan dan Belanja Negara (APBN) senantiasa ditujukan untuk mewujudkan kesejahteraan rakyat. Guna mendukung pemerataan pembangunan, APBN tahun 2015 telah mengalokasikan Dana Transfer Daerah sebesar Rp. 592,6 triliun atau 32,2 persen terhadap belanja negara. Jumlah tersebut meningkat 10,7 persen jika dibandingkan dengan pagu dalam APBNP 2014 sebesar Rp 529,4 triliun (Abidin, 2015).

Dalam perkembangannya, masyarakat di daerah khususnya di wilayah pedesaan, masih menghadapi kemiskinan, keterbelakangan dan kesulitan dalam mengakses pelayanan publik. Kondisi ini mendorong kesadaran perlunya pemerataan pembangunan dan dukungan keuangan publik (APBN) bagi masyarakat desa. Alokasi APBN bagi desa diharapkan dapat menarik keterlibatan masyarakat dalam pembangunan.

Pembangunan di tingkat desa sudah sejak lama digulirkan dengan adanya bantuan dari pemerintah yaitu dengan alokasi dana desa yang diambil dari 10\% dana APBD, sejak terbitnya Undang-undang Nomor 6 Tahun 2014 Tentang Desa maka pembangunan desa bisa dilakukan dengan dana desa. Dari jumlah total anggaran dana desa, Kabupaten Buru memiliki total dana desa sebesar 65.863.399.000. Hal ini merupakan jumlah yang tidak sedikit apabila kemudian disebarkan pada desa yang ada di Kabupaten Buru. Namun sesuai dengan amanat Peraturan Menteri Desa yang menyebutkan bahwa dana desa diprioritaskan untuk membiayai belanja pembangunan dan pemberdayaan masyarakat desa. Dengan adanya dana desa ini maka setiap desa wajib melakukan pembangunan desa, terutama dalam bidang pengembangan potensi ekonomi lokal.

Tangkumahat dalam penelitiannya tentang dampak program dana desa (2017) menunjukkan program dana desa di Kecamatan Pineleng berjalan cukup baik, namun untuk kedepannya diperlukan adanya peningkatan kapasitas dan skill dari aparatur pemerintah desa dalam rangka mendukung pelaksanaan program ini guna meningkatkan ekonomi dan kesejahteraan masyarakat yang lebih baik. Selain itu diperlukan juga relasi kepala desa dengan BPD untuk 
menjaga eksistensi dan optimalisasi pelaksanaan program dana desa (Tangkumahat, Panelewen, \& Mirah, 2017). Selain itu Daraba (2017) Hasil penelitian di Kecamatan Galesong menjelaskan bahwa Partisipasi masyarakat desa dimulai sejak penyusunan Rencana Pembangunan Jangka Menengah (RPJM), Rencana Kerja Pembangunan Desa (RKPDes), Anggaran Pendapatan Belanja (APBDes), pelaksanaan pembangunan desa, dan memanfaatkan hasil-hasil pembangunan desa. Program dana desa berpengaruh positif dan signifikan terhadap tingkat partisipasi masyarakat desa dan relasi antar stakeholder desa (Daraba, 2017).

Permasalahan pokok yang ingin diteliti dalam kajian ini berupaya mendeskripsi relasi kepala desa dan BPD dalam pemanfaatan dana desa, kajian ini dilakukan berdasarkan preferensi kepala desa dan Badan Perwakilan Desa di Kecamatan Namlea dalam pelaksanaan program dana desa. Selain itu, penelitian ini bertujuan untuk mendapatkan gambaran primer tentang relasi yang terbangun dengan konsekuensi logis yang berdampak pada pemanfaatan dana desa di Kecamatan Namlea serta menjadi penting mengingat besarnya peran kedua struktur tersebut dalam program dana desa

\section{METODE PENELITIAN}

Penelitian dilaksanakan di Kecamatan Namlea, Kabupaten Buru. Penentuan lokasi dilakukan secara purposive (sengaja). Desa Namlea, Marloso, dan Lala dipilih sebagai lokasi penelitian karena memiliki karakteristik masyarakat yang dianggap mewakili representative masyarakat di Kecamatan Namlea. Desa Namlea merupakan pusat ibukota kabupaten terdiri dari pencampuran berbagai etnik dan sebagian besar merupakan pendatang dengan mata pencaharian yang dominan di bidang jasa, sementara Marloso merupakan wilayah administrasi desa merupakan percampuran etnis Buton dan masyarakat lokal dengan bermata pencaharian sebagai petani, sedangkan Lala merupakan sebuah model desa dengan pencampuran etnis Sula dengan masyarakat lokal dengan bermata pencaharian di sektor jasa dan perikanan.

Jumlah informan yang akan diwawancara sebanyak 40 orang yang diambil secara purposive dengan pertimbangan informan dianggap sebagai pihak-pihak yang terkait untuk mencapai tujuan penelitian. Informan merupakan perangkat desa, anggota BPD, perwakilan tokoh masyarakat, tokoh adat dan pemuka agama ditambah dengan perwakilan masyarakat yang dianggap memiliki kompetensi terkait tujuan penelitian yakni berupaya mendeskripsikan relasi kepala desa dan BPD dalam pembangunan masyarakat.

Data pada penelitian ini diperoleh dari sumber data primer dan data sekunder, dengan teknik pengumpulan data yang digunakan melalui observasi, wawancara, kuesioner dan studi pustaka/dokumen. Dalam langkah wawancara peneliti melakukan wawancara mendalam 
dengan pihak terkait serta memberikan kuesioner kepada masyarakat di lokasi tersebut sebagai tanggapan atas relasi kepala desa dengan BPD terkait penggunaan anggaran desa. Peneliti juga mencari informasi pelengkap terkait penggunaan dana desa di Kecamatan Namlea melalui internet maupun studi pustaka menggunakan dokumen/arsip pemerintah yang terkait dengan kebijakan dana desa. (Hidayat, 2002).

Teknik analisis yang digunakan dalam penelitian ini adalah analisis data kualitatif mengikuti konsep yang diberikan Miles and Huberman dan Spradley. Miles and Huberman, mengemukakan bahwa aktivitas dalam analisis data kualitatif dilakukan secara interaktif dan berlangsung secara terus menerus pada setiap tahapan penelitian sehingga sampai tuntas, dan datanya sampai jenuh. Aktivitas dalam analisis data yaitu reduksi data (data reduction), penyajian data (data display), penarikan kesimpulan atau verifikasi (conclusion drawing/ verification

\section{KERANGKA KONSEP}

Desa atau yang disebut dengan nama lain telah ada sebelum Negara Kesatuan Republik Indonesia terbentuk. Sebagai bukti keberadaannya, Penjelasan Pasal 18 Undang-Undang Dasar Negara Republik Indonesia Tahun 1945 (sebelum perubahan) menyebutkan bahwa "Dalam territori Negara Indonesia terdapat lebih kurang 250 "Zelfbesturende landschappen" dan "Volksgemeenschappen", seperti desa di Jawa dan Bali, Nagari di Minangkabau, dusun dan marga di Palembang, dan sebagainya. Secara substantif Undang-Undang Desa ini menyiratkan adanya upaya pemberdayaan aparatur pemerintah desa dan juga masyarakat desa. Pemerintahan desa keberadaannya adalah berhadapan langsung dengan masyarakat, sebagai ujung tombak pemerintahan yang terdepan. Pelaksanaan otonomisasi desa yang bercirikan pelayanan yang baik adalah dapat memberikan kepuasan bagi masyarakat yang memerlukan karena cepat, mudah, tepat dan dengan biaya yang terjangkau, oleh karena itu pelaksanaan di lapangan harus didukung oleh faktor-faktor yang terlibat dalam implementasi kebijakan tentang desa tersebut.

Pengertian kepala desa menurut Dwipayana adalah sebutan pemimpin desa di Indonesia. Kepala desa merupakan pimpinan tertinggi dari pemerintah desa. Masa jabatan kepala desa adalah 6 (enam) tahun, dan dapat diperpanjang lagi untuk satu kali masa jabatan berikutnya. Kepala desa tidak bertanggung jawab kepada camat, namun hanya dikoordinasikan saja oleh camat. Jabatan kepala desa dapat disebut dengan nama lain, misalnya wali nagari (Sumatera Barat), pambakal (Kalimantan Selatan), hukum tua (Sulawesi Utara), perbekel (Bali), kuwu (Cirebon dan Indramayu) ("Relasi Antara Kepala Desa Dan Badan Permusyawaratan Desa Dalam Mewujudkan Kepemerintahan Yang Baik (Suatu Studi Di Desa Pinaling Kecamatan Amurang Timur Kabupaten Minahasa Selatan),” 2016). 
Badan perwakilan desa adalah lembaga lembaga yang melaksanakan fungsi pemerintahan yang anggotanya merupakan wakil dari penduduk desa berdasarkan keterwakilan wilayah dan ditetapkan secara demokratis. Badan Perwakilan desa berfungsi membahas dan menyepakati rancangan peraturan desa bersama kepala desa, menampung dan menyalurkan aspirasi masyarakat, melakukan pengawasan kinerja kepala desa. BPD berkedudukan sebagai unsur penyelenggara pemerintahan desa. Anggota BPD berasal dari komponen-komponen di masyarakat desa kini telah tampil menjadi salah satu pimpinan desa berpengaruh. Anggotaanggota BPD terdiri dari para pemuka di masyarakat yang dipilih oleh warga desa telah menjadi pimpinan di organisasi yang ada di desa dan tidak dibenarkan apabila anggota BPD merangkap sebagai kepala desa atau perangkat desa (Awaeh, Linda Lambey, \& Pinatik, 2017).

Kepala desa merupakan unit pemerintah tertinggi desa yang bertanggung jawab penuh atas kesejahteraan masyarakat desa yang diaturnya, sehingga efektivitas kepala desa sangat menentukan maju tidaknya desa tersebut. Dibutuhkan pula pengawas yang berfungsi untuk mengawasi kinerja pemerintahan kepala desa yang disebut dengan badan Perwakilan desa atau yang sering disebut dengan BPD. Dengan adanya BPD, maka akan tercapai keseimbangan kinerja pemerintahan desa. Selain fungsi pengawasan dibentuknya BPD juga berfungsi dalam penampung dan penyalur aspirasi masyarakat desa serta fungsi legislasi yaitu ikut berperan dalam pembuatan Peraturan Desa bersama- sama kepala desa, dimana Peraturan Desa tersebut kemudian akan dipertanggung jawabkan dan dilaporkan kepada Bupati. Dana desa adalah dana yang bersumber dari anggaran pendapatan dan belanja negara yang diperuntukkan bagi desa dan desa adat yang ditransfer melalui anggaran pendapatan dan belanja daerah kabupaten/kota dan digunakan untuk membiayai penyelenggaraan pemerintahan, pembangunan, serta pemberdayaan masyarakat, dan kemasyarakatan. Fokus penting dari penyaluran dana ini lebih terkait pada implementasi pengalokasian dana desa agar bisa sesempurna gagasan para inisiatornya. Skenario awal dana desa ini diberikan dengan mengganti program pemerintah yang dulunya disebut Program Nasional Pemberdayaan Masyarakat (PNPM), namun dengan berlakunya dana desa ini, dapat menutup kesempatan beberapa pihak asing untuk menyalurkan dana ke daerah di Indonesia dengan program-program yang sebenarnya juga dapat menjadi pemicu pembangunan daerah.

Berdasarkan Peraturan Pemerintah Nomor 60 Tahun 2014 tentang dana desa yang bersumber dari APBN, dengan luasnya lingkup kewenangan desa dan dalam rangka mengoptimalkan penggunaan dana desa, maka penggunaan dana desa diprioritaskan untuk membiayai pembangunan dan pemberdayaan masyarakat desa. Penetapan prioritas penggunaan dana tersebut tetap sejalan dengan kewenangan yang menjadi tanggung jawab desa. Dalam 
kewenangan tersebut perlu adanya sinergitas melalui relasi yang terbangun antara kepala desa dengan BPD sebagai upaya pelaksanaan yang optimal.

Relasi menurut George Hillery jr, adalah sekelompok orang yang tinggal didaerah tertentu yang memiliki hubungan interaksi satu sama lain yang menjadikan kelompok itu saling mengenal satu sama lain dalam sebuah lingkungan kelompok manusia tersebut. Sementara menurut Drs. Abdul Chear (2008) mengemukakan bahwa relasi merupakan hubungan kemaknaan,antara organisasi dengan komunitas terdapat hubungan saling ketergantungan sehingga memotivasi organisasi untuk melakukan hubungan yang saling menguntungkan. Menurut Astuti (2012) relasi juga disebut hubungan sosial merupakan hasil dari interaksi (rangkaian tingkah laku) yang sistematik antara dua orang atau lebih. Dengan demikian, penulis menyimpulkan bahwa relasi merupakan hubungan timbal balik antara organisasi dengan individu yang lain atau masyarakat lain dan saling mempengaruhi. Sikap publik terhadap suatu organisasi dimasa depan juga amat bergantung bagaimana informasi yang diperoleh mengenai organisasi, ataupun bagaimana public menyampaikan apa yang dirasakan mengenai organisasi (Kusumastuti, 2017).

Relasi antara pemerintah desa dan badan Perwakilan desa yang dimaksudkan dalam penelitian ini merupakan hubungan kerja dalam membuat dan menetapkan pelaksanaan dana desa sebagai hubungan dalam penyelenggaraan pemerintahan desa yaitu hubungan kerja antara kepala desa dengan badan Perwakilan desa, dimana kepala desa memiliki hubungan kerja di dalam menetapkan kebijakan bersama BPD dan menetapkan penggunaan dana desa yang telah mendapat persetujuan BPD.

Relasi yang terbentuk mengarah pada koordinasi dimana telah diatur oleh undang-undang desa dimana koordinasi merupakan penempatan berbagai kegiatan yang berbeda-beda pada keharusan tertentu sesuai dengan aturan yang berlaku untuk mencapai tujuan sebaik-baiknya dengan proses yang telah ditetapkan. Sebagaimana yang telah diatur posisi kepala desa memberikan ruang tugas untuk menyelenggarakan urusan pemerintahan, antara lain pengaturan kesejahteraan masyarakat sesuai dengan kewenangan desa, pembuatan peraturan desa, pembentukan lembaga kemasyarakatan, pembentukan badan usaha milik desa (BUMD), dan kerja sama antar desa, urusan pembangunan, antara lain pemberdayaan masyarakat dalam penyediaan sarana prasarana fasilitas umum desa semacamnya, jalan desa, jembatan desa, pengairan desa, pasar desa, dan urusan kemasyarakatan, yang meliputi pemberdayaan masya-rakat melewati pembinaan sosial budaya masyarakat, bidang kesehatan, pendidikan dan budaya istiadat. Sementara BPD memiliki ruang untuk membahas dan menyepakati rancangan peraturan desa bersama kepala desa, menampung dan menyalurkan aspirasi masyarakat desa dan melakukan pengawasan kinerja kepala desa. 


\section{PEMBAHASAN}

Inti dari pembangunan adalah proses yang berkesinambungan perubahan yang kemajuan dan peningkatan ke arah yang telah ditentukan. "Pembangunan adalah usaha atau serangkaian pertumbuhan bisnis dan perencanaan perubahan yang dibuat secara sadar oleh bangsa, negara dan pemerintah untuk modernitas dalam rangka pembangunan bangsa" (Siagian, 2004). Pembangunan adalah proses perubahan ke arah yang lebih baik melalui upaya terencana. Dalam proses perencanaan dan pelaksanaan pembangunan desa, pemerintah desa disertai oleh Pemerintah Kabupaten / kota yang secara teknis dilaksanakan oleh unit perangkat kabupaten / kota. Untuk mengkoordinasikan pengembangan Desa, kepala desa dapat disertai oleh tenaga profesional escort, kader pemberdayaan masyarakat desa, dan atau pihak ketiga. sebutan lainnya akan berkoordinasi mentoring di wilayah tersebut. pembangunan desa meliputi bidang pemerintahan desa, pelaksanaan pembangunan desa, pembangunan masyarakat desa dan pemberdayaan masyarakat desa.

Untuk ini, peneliti mewawancarai GK informan yang mengatakan bahwa dalam perencanaan pembangunan umumnya ada harus memerlukan analisis dan identifikasi yang bertujuan untuk mengurai program yang akan direncanakan untuk menyesuaikan pembangunan kebutuhan di desa Namlea, oleh karena penyebaran pemerintah desa di kecamatan Namlea membentuk tim khusus yang terdiri dari perangkat desa serta anggota masyarakat yang memiliki sumber daya yang terkait dengan bidang perencanaan bertugas melakukan analisis dan identifikasi yang terkait dengan perencanaan pembangunan dari jumlah pendek, jangka menengah-baik atau jangka panjang pembangunan yang kemudian akan dituangkan dalam rencana pembangunan jangka menengah desa (RPJMDes) serta hasil wawancara dengan informan dari JL mengatakan bahwa dalam perencanaan pembangunan harus melalui proses analisis dan identifikasi, terkait dengan proses analisis dan identifikasi secara administratif-sangat dalam pemberitahuan tersebut, sebagai pejabat administrasi tentu saja mengidentifikasi dan menganalisis secara administratif dan kemudian memberikan pertimbangan dalam melakukan perencanaan pembangunan.

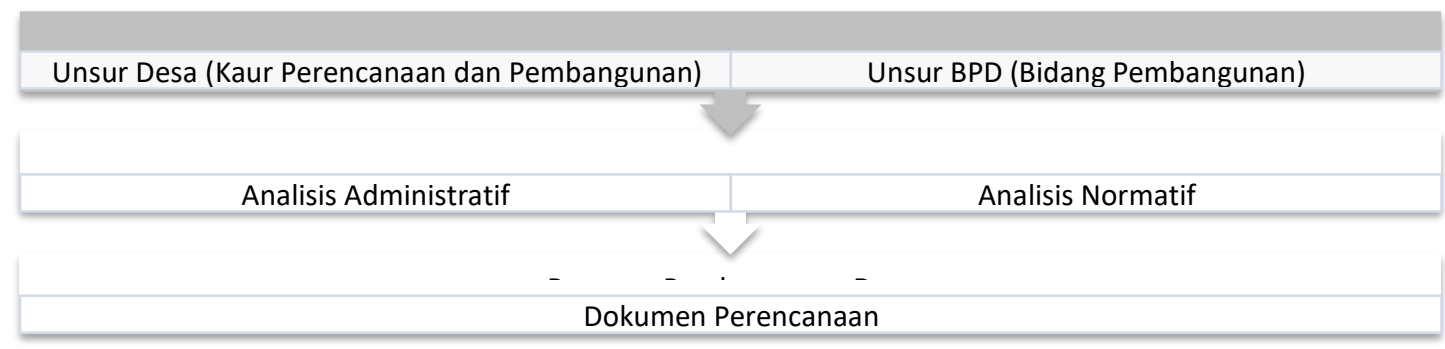

Gambar 1. Proses Perencanaan Pembangunan Desa

Berdasarkan informasi yang peneliti temukan di lapangan melalui wawancara dengan berbagai pemangku kepentingan, dalam perencanaan pembangunan yang dilakukan di desa-desa seperti

I36 | SOSIOGLLBAL : Jurnal Pemikiran dan Penelitian Sosiologi, Vol. 4, No. 2, Juni 2020 
Namlea, Marloso, dan Lala mereka melakukan analisis dan identifikasi kegiatan yang akan dilakukan dalam rangka pembangunan, tetapi juga beberapa pihak yang menganggap bahwa analisis dan identifikasi hanya dilakukan secara normatif.

Menyadari sepenuhnya bahwa kegiatan pembangunan bukan sekedar bersifat fisik dan terkait dengan pemanfaatan sumber daya alam yang jelas mengandung resiko mengubah ekosistem yang ada serta akan menimbulkan dampak, maka pemetaan usulan yang terjadi antara pemerintah desa dengan BPD dapat dilihat seperti yang disajikan pada gambar berikut ini:

Pemetaan Usulan Penggunaan Dana Desa Namlea, Marloso dan Lala

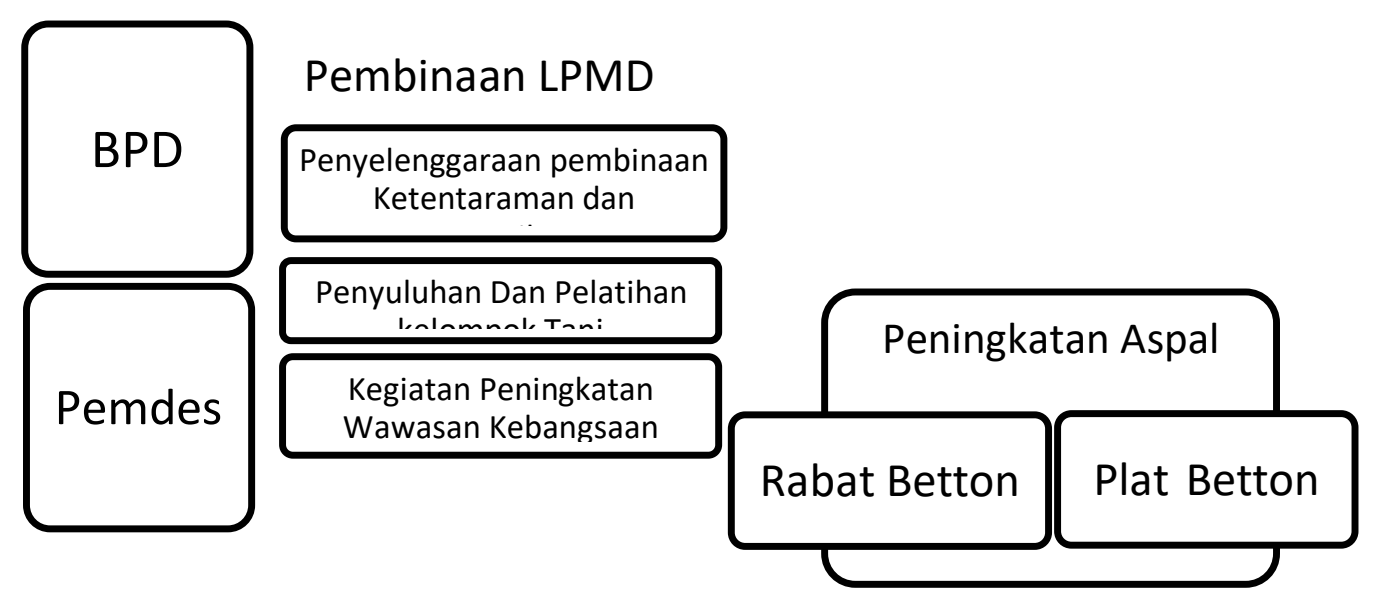

Gambar 2. Pemetaan Usulan Penggunaan Desa

Gambar 2 mengindikasikan bahwa BPD lebih mengutamakan pemanfaatan pada sektor pembinaan maupun peningkatan kesadaran masyarakat sementara pemerinta desa lebih menonjolkan perencanaan pekerjaan fisik. Berdasarkan hasil wawancara yang peneliti lakukan beberapa pihak menyampaikan pendapat diantaranya kepala desa, ketua BPD dan tokoh masyarakat mengatakan bahwa pemetaan perencanaan pembangunan melalui penggunaan dana desa di desa Namlea, Marloso dan Lala lebih mengacu pada beberapa kondisi yang ada di desa yang paling penting bahwa perencanaan dan pelaksanaan telah melalui koordinasi dan musyawarah antar lembaga di masing-masing desa.

Adapun hubungan kerjasama yang terbangun merupakan pembagian kerja antara pemerintah desa dan BPD. Perbandingan draf rancangan pemanfaatan dana desa di desa Namlea, Marloso dan Lala dapat digambarkan bahwa pemanfaatan dana desa untuk peningkatan keterampilan, penguatan modal usaha merupakan adalah unsur fokus yang diinisiasi oleh BPD, sementara pemerintah desa lebih memfokuskan pada penguatan modal usaha dan penyelenggaraan pelatihan dan kursus untuk wirausaha. 
Salma Yusuf, M Chairul Basrun Umanailo, Nirwana AR

Tabel 1. Peran Kelembagaan Dalam Usulan Pemanfaatan Dana Desa

\begin{tabular}{|c|c|c|}
\hline \multirow[t]{2}{*}{ Lembaga } & \multicolumn{2}{|c|}{ Pembangunan Desa } \\
\hline & Perencanaan & Pelaksanaan \\
\hline \multirow[t]{6}{*}{ Pemerintahan Desa } & $\begin{array}{l}\text { Penguatan modal Badan Usaha } \\
\text { Milik Desa }\end{array}$ & $\begin{array}{l}\text { Pemberian bantuan modal usaha } \\
\text { untuk Badan Usaha Milik Desa }\end{array}$ \\
\hline & Peningkatan keterampilan usaha & $\begin{array}{l}\text { Penyelenggaraan kursus dan } \\
\text { pelatihan }\end{array}$ \\
\hline & $\begin{array}{l}\text { Peningkatan minat baca } \\
\text { masyarakat }\end{array}$ & Penambahan jumlah buku baca \\
\hline & Peningkatan mutu lingkungan & $\begin{array}{l}\text { Pelaksanaan gerakan jumat bersih } \\
\text { dan kerja bakti masyarakat pada } \\
\text { hari minggu }\end{array}$ \\
\hline & $\begin{array}{l}\text { Pengisian kekosongan perangkat } \\
\text { desa }\end{array}$ & Pelaksanaan pemilihan kepala desa \\
\hline & Peningkatan layanan informasi & Pengadaan papan informasi desa \\
\hline \multirow[t]{9}{*}{$\begin{array}{l}\text { Badan Perwakilan } \\
\text { Desa }\end{array}$} & Penguatan ekonomi desa & $\begin{array}{l}\text { Inventarisasi lembaga ekonomi } \\
\text { desa }\end{array}$ \\
\hline & Penguatan Badan Usaha Milik & Pemberian modal usaha untuk \\
\hline & Desa & Badan Usaha Milik Desa \\
\hline & $\begin{array}{l}\text { Peningkatan ekonomi } \\
\text { masyarakat Miskin }\end{array}$ & $\begin{array}{l}\text { Pembinaan dan pelatihan } \\
\text { pengelolaan sumberdava lokal }\end{array}$ \\
\hline & $\begin{array}{l}\text { Mendukung peningkatan mutu } \\
\text { lingkungan }\end{array}$ & $\begin{array}{l}\text { Pelaksanaan kerja bakti masyarakat } \\
\text { secara rutin }\end{array}$ \\
\hline & Mendukung pengambangan & Bantuan pengadaan peralatan \\
\hline & budaya lokal & kesenian \\
\hline & Pembinaan dan pengembangan & Pelaksanaan mengaji desa setiap \\
\hline & kelompok pengajian & hari kamis \\
\hline
\end{tabular}

Sumber: Pengolahan Data Primer Maret-Juni 2019

Dari tabel di atas tergambar bahwa pemerintah desa, membuat usulan program dengan mengacu pada program kerja pemerintahan desa, sesuai yang disampaikan oleh salah satu informan $(\mathrm{KH})$ "usulan pemanfaatan dana desa dari pihak desa lebih mengutamakan usulan pembangunan yang telah disiapkan sebelumnya melalui mekanisme rapat desa. Sementara untuk BPD usulan merupakan aspirasi yang ditampung melalui media musyawarah maupun diskusi yang dilakukan oleh beberapa anggota BPD.

Menurut Solekhan sebagai unsur pemerintahan desa, pemerintah desa memiliki tugas untuk melakukan pemerintahan, pembangunan, dan urusan sosial. Oleh karena itu, bila dilihat dari segi fungsi, pemerintah desa memiliki fungsi: 1) melakukan urusan dalam pemerintahan desa, 2) melaksanakan pembangunan dan pembangunan masyarakat, 3) melaksanakan pembangunan ekonomi desa, 4) melaksanakan Partisipasi pembangunan dan saling membantu, 5) melaksanakan Pembangunan ketentraman masyarakat, 6) melakukan penyelesaian sengketa musyawarah, dan lain sebagainya (Sidik, 2015). Berkenaan dengan tugas dan fungsi masingmasing lembaga, hubungan antara kepala desa dengan BPD adalah kemitraan dan didasarkan

138 | SGSIOGLOBAL : Jurnal Pemikiran dan Penelitian Sasiolagi, Vol. 4, No. 2, Juni 2020 
pada prinsip check and balances. Oleh karena itu, proses pemerintahan desa harus membuka ruang bagi demokrasi substantif. Dengan demikian, hubungan kemitraan antara kepala desa dan BPD harus bergantung pada keyakinan, kerja sama, dan aspek saling menghormati dari dua, sehingga jika tiga aspek dapat dibangun bersama-sama, itu akan menjadi Sebuah kemitraan yang harmonis antara keduanya.

\section{SIMPULAN}

Kerjasama aparatur desa dalam penyelenggaraan pemerintah desa merupakan salah satu indikator untuk melihat kinerja aparatur desa. Dalam hal ini kemampuan aparatur untuk bekerja sama dengan orang lain guna menyelesaikan tugas yang ditentukan sehingga hasil pekerjaannya akan semakin baik. Aparatur desa mengetahui kerjasama itu intinya menunjukkan adanya kesepakatan antara 2 (dua) orang atau lebih yang saling menguntungkan dengan cara memberikan informasi secara langsung kepada aparatur yang ingin kita ajak atau yang sangat dibutuhkan bantuannya untuk bekerja sama dalam suatu pekerjaan, misalnya administrasi kantor, pelayanan kepada masyarakat, pembangunan desa, dan hal-hal lain yang bertujuan untuk meningkatkan kinerja aparatur, kemudian saling bermusyawarah antara aparatur di Kantor Desa Kayeli.

Dengan demikian untuk menyelesaikan pekerjaannya masing-masing aparat desa harus melakukan kerjasama dengan rekan kerjanya yang diharapkan mampu untuk membantu menyelesaikan pekerjaan yang dibebankan kepadanya, dimana aparatur tersebut berkolaborasi dengan rekan kerja dalam satu pekerjaan agar pekerjaan tersebut dapat selesai tepat pada waktunya.

Analisis dan identifikasi dalam tahap perencanaan pembangunan desa di kecamatan Namlea telah dilakukan dengan cukup baik, tetapi tidak secara maksimal tetapi keterlibatan adalah langkah maju dalam mencapai partisipasi masyarakat secara umum. Keterlibatan lembaga desa untuk pengelolaan dana desa memungkinkan untuk kolaborasi ide dan sumber daya sehingga pada tahap implementasi dana desa dapat dihasilkan optimasi untuk mencapai target.

\section{DAFTAR PUSTAKA}

Abidin, M. Z. 2015. Tinjauan Atas Pelaksanaan Keuangan Desa dalam Mendukung Kebijakan Dana Desa. Jurnal Ekonomi \& Kebijakan Publik. https://doi.org/http://dx.doi.org/10.22212/jekp.v6i1.156

Awaeh, M., Linda Lambey, L., \& Pinatik, S. 2017. Analisis Efektivitas Penerapan Tax Amnesty (Pengampunan Pajak) Terhadap Penerimaan Pajak Pada Kantor Pelayanan Pajak Pratama Bitung. Jurnal EMBA: Jurnal Riset Ekonomi, Manajemen, Bisnis Dan Akuntansi.

BPS-Statistics Indonesia. 2017. Statistical Yearbook of Indonesia 2017. BPS-Statistics Indonesia. 
Salma Yusuf, M Chairul Basrun Umanaila, Nirwana AR

https://doi.org/10.2307/2541047

Daraba, D. 2017. Pengaruh Program Dana Desa Terhadap Tingkat Partisipasi Masyarakat Di

Kecamatan Galesong Utara Kabupaten Takalar. Sosiobumaniora.

https://doi.org/10.24198/sosiohumaniora.v19i1.11524

Hidayat, D. N. 2002. Metodologi Penelitian dalam Sebuah "Multi-Paradigm Science." Mediator: Jurnal Komunikasi. https://doi.org/10.29313/MEDIATOR.V3I2.766

Kusumastuti, A. 2017. Modal Sosial dan Mekanisme Adaptasi Masyarakat Pedesaan dalam

Pengelolaan dan Pembangunan Infrastruktur. MASYARAKAT: Jurnal Sosiologi, 20(1), 81-97. https://doi.org/10.7454/mjs.v20i1.4740

Relasi Antara Kepala Desa Dan Badan Permusyawaratan Desa Dalam Mewujudkan Kepemerintahan Yang Baik (Suatu Studi Di Desa Pinaling Kecamatan Amurang Timur Kabupaten Minahasa Selatan). (2016). Jurnal Eksekutif.

Siagian, V. 2004. Analisa Sumber-Sumber Pertumbuhan Ekonomi Filipina Periode 1994-2003. Jurnal Perdagangan.

Sidik, F. 2015. Menggali Potensi Lokal Mewujudkan Kemandirian Desa. JKAP Jurnal Kebijakan Dan Administrasi Publik). https://doi.org/10.22146/jkap.7962

Tangkumahat, F. V., Panelewen, V. V. J., \& Mirah, A. D. P. (2017). Dampak Program Dana Desa Terhadap Peningkatan Pembangunan Dan Ekonomi Di Kecamatan Pineleng Kabupaten Minahas. Agri-Sosioekonomi.

https://doi.org/10.35791/agrsosek.13.2a.2017.17130

140 | SOSIOGLZBAL : Jurnal Pemikiran dan Penelitian Sosiologi, Vol. 4, №. 2, Juni 2020 